\title{
Formation Mechanism of CaS-Bearing Inclusions and the Rolling Deformation in Al-Killed, Low-Alloy Steel with Ca Treatment
}

\author{
GUANG XU, ZHOUHUA JIANG, and YANG LI
}

The existing form of $\mathrm{CaS}$ inclusion in Ca-treated, Al-killed steel during secondary refining process was investigated with scanning electron microscopy and an energy-dispersive spectrometer (EDS). The results of 12 heats industrial tests showed that CaS has two kinds of precipitation forms. One form takes place by the direct reaction of $\mathrm{Ca}$ and $\mathrm{S}$, and the other takes place by the reaction of $\mathrm{CaO}$ in calcium aluminates with dissolved $\mathrm{Al}$ and $\mathrm{S}$ in liquid steel. Thermodynamic research for different precipitation modes of $\mathrm{CaS}$ under different temperature was carried out. In particular, $\mathrm{CaO}-\mathrm{Al}_{2} \mathrm{O}_{3}-\mathrm{CaS}$ isothermal section diagrams and component activities of calcium aluminates were calculated by the thermodynamic software FactSage. By thermodynamic calculation, a precipitation-area diagram of oxide-sulfide duplex inclusion was established by fixing the sulfur content. The quantity of $\mathrm{CaS}$, which was precipitated in a reaction between $[\mathrm{Al}],[\mathrm{S}]$ and $(\mathrm{CaO})$, can be calculated and predicted based on the precipitation-area diagram of oxide-sulfide duplex inclusion. Electron probe microanalysis and EDS were used for observing rolling deformation of different types of CaS-bearing inclusions during the rolling process. Low modification of calcium aluminates wrapped by $\mathrm{CaS}$ has different degrees of harm to steel in the rolling process. A thick CaS layer can prevent some fragile calcium aluminates from being crushed during the rolling process. Some oxide-sulfide duplex inclusion contains little CaS performed better deformation during the rolling process, but when $\mathrm{CaS}$ in oxide-sulfide duplex inclusion becomes more, it will cause the whole inclusion to lose plastic yielding ability. The plastic deformation region of CaS-bearing inclusion in a $\mathrm{CaO}-\mathrm{Al}_{2} \mathrm{O}_{3}-\mathrm{CaS}$ isothermal section diagram is confirmed.

DOI: $10.1007 / \mathrm{s} 11663-016-0695-9$

(C) The Author(s) 2016. This article is published with open access at Springerlink.com

\section{INTRODUCTION}

Calcium treatment is widely used for inclusion modification in Al-killed steel. It makes the inclusions modify liquid globular calcium aluminates, which are easier to float up and to be absorbed by top slag, thereby improving the cleanness of steel. Although calcium has good modification ability to the inclusion in Al-killed steel, improper calcium treatment will bring adverse effects. Insufficient calcium treatment promotes the inclusion into solid calcium aluminates, which are hard to be removed. For excessive calcium treatment, redundant calcium will react directly with sulfur to form $\mathrm{CaS}$ inclusion. At the same time, the dissolved aluminum and sulfur in molten steel will react with $\mathrm{CaO}$ in excessive modification of calcium aluminates to form oxide-sulfur duplex inclusion, so that a large number of CaS-bearing inclusions will form after excessive calcium treatment. CaS-bearing inclusions can degrade the castability of steel

GUANG XU, Doctoral Candidate, and ZHOUHUA JIANG and YANG LI, Professors, are with the School of Materials and Metallurgy, Northeastern University, 241 Mailbox, No. 3-11, Wenhua Road, Heping District, Shenyang, 110819, P.R. China. Contact e-mail: jiangzh263@163.com

Manuscript submitted March 10, 2016.

Article published online May 26, 2016. on account of its high melting point and lead to erosion of the ladle slide gate as well as refractory nozzles during casting. ${ }^{[1]}$ Several researchers have examined the formation mechanism of oxide-sulfide duplex inclusion and its rolling performance. Ye et al. ${ }^{[2]}$ considered that dissolved aluminum and sulfur can react with $\mathrm{CaO}$ in complete or overmodified aluminum inclusion due to its high activity of CaO. Holappa et al. ${ }^{[3]}$ pointed out that $\mathrm{CaS}$ and oxide-sulfide duplex inclusion is promoted by enrichment of sulfur in the liquid residual as well as by the decreasing of temperature. Choudary and Ghosh ${ }^{[4]}$ established a thermodynamic model to forecast the formation of oxide-sulfide duplex inclusion generated from the reaction between [Al], [S] and liquid calcium aluminates in Al-killed steel. However, thermodynamic investigations of them only aimed at the Al-S equilibriums of CA, $\mathrm{C}_{12} \mathrm{~A}_{7}$, and $\mathrm{C}_{3} \mathrm{~A}$ (where $\mathrm{A}$ means $\mathrm{Al}_{2} \mathrm{O}_{3}$ and $\mathrm{C}$ means $\mathrm{CaO}$ ) for the precipitation of $\mathrm{CaS}$ in oxide-sulfide duplex inclusion. The authors of this article thinks that Al-S equilibriums of $\mathrm{CA}, \mathrm{C}_{12} \mathrm{~A}_{7}$, and $\mathrm{C}_{3} \mathrm{~A}$ alone cannot forecast the precipitation of $\mathrm{CaS}$ accurately because the $a_{\mathrm{CaO}}$ of each calcium aluminate is different and they should not be replaced by the $a_{\mathrm{CaO}}$ of $\mathrm{CA}, \mathrm{C}_{12} \mathrm{~A}_{7}$, or $\mathrm{C}_{3} \mathrm{~A}$. It is worth mentioning that the research about how much $\mathrm{CaS}$ can be produced by the reaction between $[\mathrm{Al}],[\mathrm{S}]$ and $(\mathrm{CaO})$ is scarcely reported in the published literature. Jing Guo et al. ${ }^{[5]}$ found that oxide-sulfide duplex inclusion has good rolling 
performance. But when $\mathrm{CaS}$ in the oxide-sulfide inclusion increases, its rolling performance may become worse. Some CaS-bearing inclusions contain low modification of core that were not researched extensively in their study, so it is difficult to reveal the change law of the deformation of CaS-bearing inclusions during the rolling process.

In the present work, the thermodynamics for different precipitation methods of $\mathrm{CaS}$ under different temperatures and deformation behaviors of various types of CaS-bearing inclusions during the rolling process were studied. In particular, more calcium aluminates were considered in thermodynamic calculation of Al-S equilibrium and $\mathrm{Ca}-\mathrm{Al}$ equilibrium. One kind of precipitation-area diagram for oxide-sulfur duplex inclusion was established by combining Al-S equilibrium with $\mathrm{Ca}-\mathrm{Al}$ equilibrium under the condition of fixing sulfur content. For explaining the formation mechanism of oxide-sulfide duplex inclusion, an unreacted core model of evolution of the $\mathrm{CaO}-\mathrm{Al}_{2} \mathrm{O}_{3}$ system into the $\mathrm{CaO}$ $\mathrm{Al}_{2} \mathrm{O}_{3}-\mathrm{CaS}$ system was established. Furthermore, the mass fraction of $\mathrm{CaS}$ precipitated in the reaction between [Al], [S] and $(\mathrm{CaO})$ can be calculated based on the precipitation-area diagram and the model. Verification tests were carried out, and the results were in good agreement with the thermodynamic calculation. Change law of rolling performances for CaS-bearing inclusions during the rolling process were summarized by observing different CaS-bearing inclusions, and it was explained by thermodynamics with the help of the thermodynamic software FactSage. The plastic deformation region of oxide-sulfide duplex inclusion is roughly confirmed.

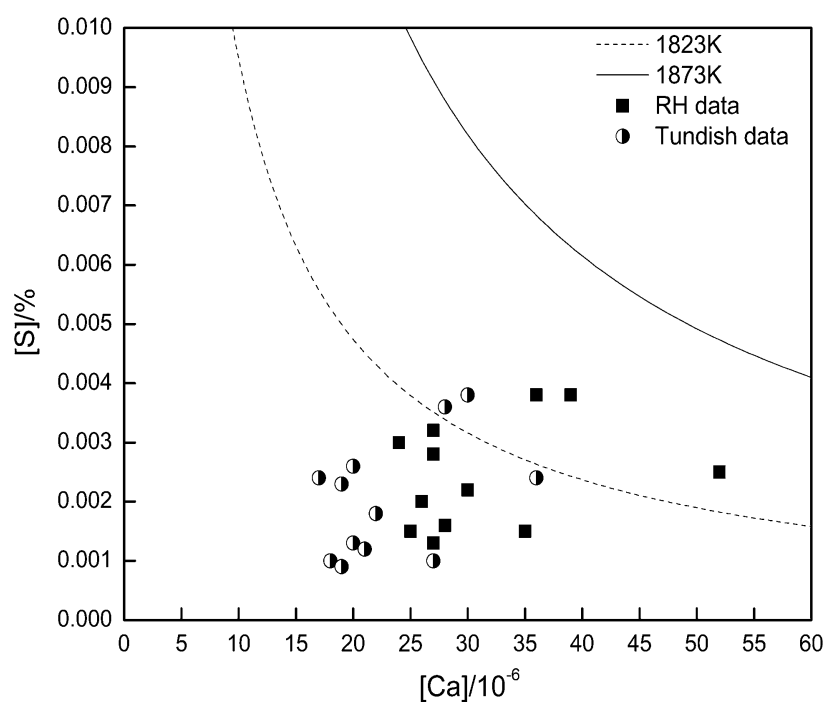

Fig. 1-Relationship between $\mathrm{Ca}$ and $\mathrm{S}$ for the precipitation of $\mathrm{CaS}$.

Table I. Chemical Composition of Liquid Steel, Mass Percent

\begin{tabular}{lccccc}
\hline Station & $\mathrm{C}$ & $\mathrm{Si}$ & $\mathrm{Mn}$ & $\mathrm{P}$ & $\mathrm{Ni}$ \\
\hline RH after calcium treatment & 0.04 to 0.045 & 0.15 to 0.20 & 1.70 to 1.80 & 0.01 to 0.015 \\
Tundish & 0.04 to 0.045 & 0.15 to 0.20 & 1.70 to 1.80 & 0.01 to 0.015 & 1.8 to 2.2 \\
Casting slab & 0.04 to 0.045 & 0.15 to 0.20 & 1.70 to 1.80 & 0.01 to 0.015 & 1.8 to 2.2 \\
\hline
\end{tabular}

Table II. Contents of $\mathrm{S}, \mathrm{Ca}$ and $\mathrm{Al}_{\mathrm{S}}$ in Liquid Steel, Mass Percent

\begin{tabular}{|c|c|c|c|c|c|c|c|c|c|c|c|c|}
\hline Heats & 1 & 2 & 3 & 4 & 5 & 6 & 7 & 8 & 9 & 10 & 11 & 12 \\
\hline $\mathrm{S}_{\mathrm{RH}}$ & 0.0020 & 0.0015 & 0.0025 & 0.0015 & 0.0032 & 0.0030 & 0.0028 & 0.0016 & 0.0038 & 0.0022 & 0.0013 & 0.0038 \\
\hline $\mathrm{S}_{\text {Tund }}$ & 0.0013 & 0.0010 & 0.0024 & 0.0010 & 0.0026 & 0.0024 & 0.0023 & 0.0012 & 0.0038 & 0.0018 & 0.0009 & 0.0036 \\
\hline $\mathrm{S}_{\text {slab }}$ & 0.0013 & 0.0009 & 0.0016 & 0.0010 & 0.0020 & 0.0020 & 0.0019 & 0.0011 & 0.0027 & 0.0016 & 0.0008 & 0.0026 \\
\hline $\mathrm{Ca}_{\mathrm{RH}}$ & 0.0026 & 0.0035 & 0.0052 & 0.0025 & 0.0027 & 0.0024 & 0.0027 & 0.0028 & 0.0039 & 0.0030 & 0.0027 & 0.0036 \\
\hline $\mathrm{Ca}_{\text {Tundish }}$ & 0.0020 & 0.0027 & 0.0036 & 0.0018 & 0.0020 & 0.0017 & 0.0019 & 0.0021 & 0.0030 & 0.0022 & 0.0019 & 0.0028 \\
\hline $\mathrm{Ca}_{\text {slab }}$ & 0.0005 & 0.0008 & 0.0020 & 0.0004 & 0.0005 & 0.0006 & 0.0006 & 0.0006 & 0.0007 & 0.0006 & 0.0004 & 0.0011 \\
\hline $\mathrm{A} 1_{\mathrm{sRH}}$ & 0.0450 & 0.0480 & 0.0450 & 0.0420 & 0.0390 & 0.0440 & 0.0410 & 0.0430 & 0.0440 & 0.0460 & 0.0420 & 0.0450 \\
\hline $\mathrm{Al}_{\text {sTundish }}$ & 0.0440 & 0.0470 & 0.0460 & 0.0430 & 0.0400 & 0.0460 & 0.0400 & 0.0410 & 0.0450 & 0.0450 & 0.0440 & 0.0460 \\
\hline $\mathrm{Al}_{\text {sslab }}$ & 0.0420 & 0.0450 & 0.0430 & 0.0410 & 0.0390 & 0.0440 & 0.0400 & 0.0400 & 0.0440 & 0.0430 & 0.0440 & 0.0450 \\
\hline
\end{tabular}

Table III. First order Interaction Coefficients Used in Thermodynamic Calculation at $1823 \mathrm{~K}$ and $1873 \mathrm{~K}\left(1550{ }^{\circ} \mathrm{C}\right.$ and $\left.1600{ }^{\circ} \mathrm{C}\right)^{[6,8]}$

\begin{tabular}{lcccccccc}
\hline & \multicolumn{9}{c}{$j$} \\
\cline { 2 - 8 }$i$ & $\mathrm{C}$ & $\mathrm{Si}$ & $\mathrm{Mn}$ & $\mathrm{Ni}$ & $\mathrm{P}$ & $\mathrm{S}$ & $\mathrm{Al}$ \\
\hline $\mathrm{S}_{1873 \mathrm{~K}\left(1600^{\circ} \mathrm{C}\right)}$ & 0.11 & 0.063 & -0.026 & 0 & 0.29 & -0.029 & 0.035 & -0.27 \\
$\mathrm{Al}_{1873 \mathrm{~K}\left(1600^{\circ} \mathrm{C}\right)}$ & 0.091 & 0.0056 & 0.0065 & - & 0.033 & 0.03 & 0.045 & -6.6 \\
$\mathrm{Ca}_{1873 \mathrm{~K}\left(1600^{\circ} \mathrm{C}\right)}$ & $-0.34^{[9]}$ & -0.097 & $-0.0156^{[10]}$ & -0.044 & -0.097 & $-336^{[11]}$ & $-0.072^{[9]}$ & $-9000^{[12]}$ \\
$\mathrm{S}_{1823 \mathrm{~K}\left(1550^{\circ} \mathrm{C}\right)}$ & $0.11^{*}$ & $0.063^{*}$ & $-0.026^{*}$ & $0^{*}$ & $0.29^{*}$ & $-0.031^{[13]}$ & $0.035^{*}$ & $-0.27^{*}$ \\
$\mathrm{Al}_{1823 \mathrm{~K}\left(1550^{\circ} \mathrm{C}\right)}$ & $0.091^{*}$ & $0.0056^{*}$ & $0.0065^{*}$ & - & $0.033^{*}$ & $0.03^{*}$ & $0.046^{[13]}$ & $-7.11^{[13]}$ \\
$\mathrm{Ca}_{1823 \mathrm{~K}\left(1550^{\circ} \mathrm{C}\right)}$ & $-0.34^{*}$ & $-0.097^{*}$ & $-0.0156^{*}$ & $-0.044^{*}$ & $-0.097^{*}$ & $-336^{*}$ & $-0.072^{*}$ & $-9000^{*}$ \\
\hline
\end{tabular}



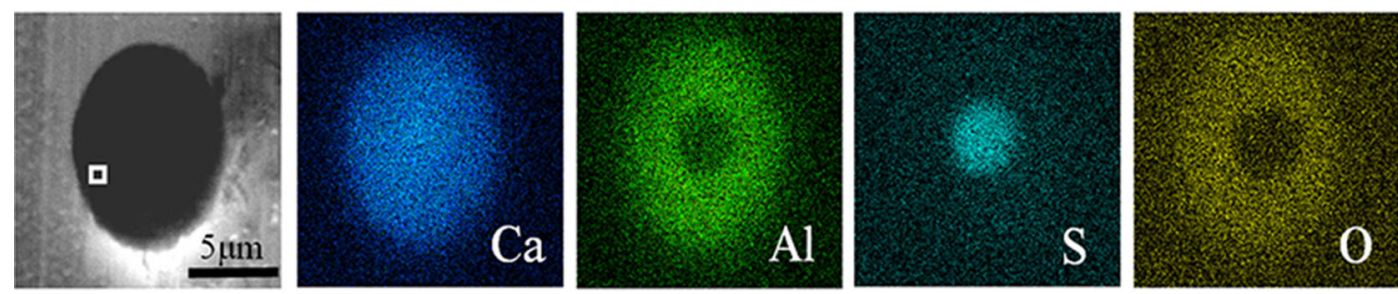

$\mathrm{CaO}: 34.1$ mass $\%$

$\mathrm{Al}_{2} \mathrm{O}_{3}: 64.2$

$\mathrm{MgO}: 1.7$

Fig. 2-SEM mapping of CaS wrapped by calcium aluminates after calcium treatment.

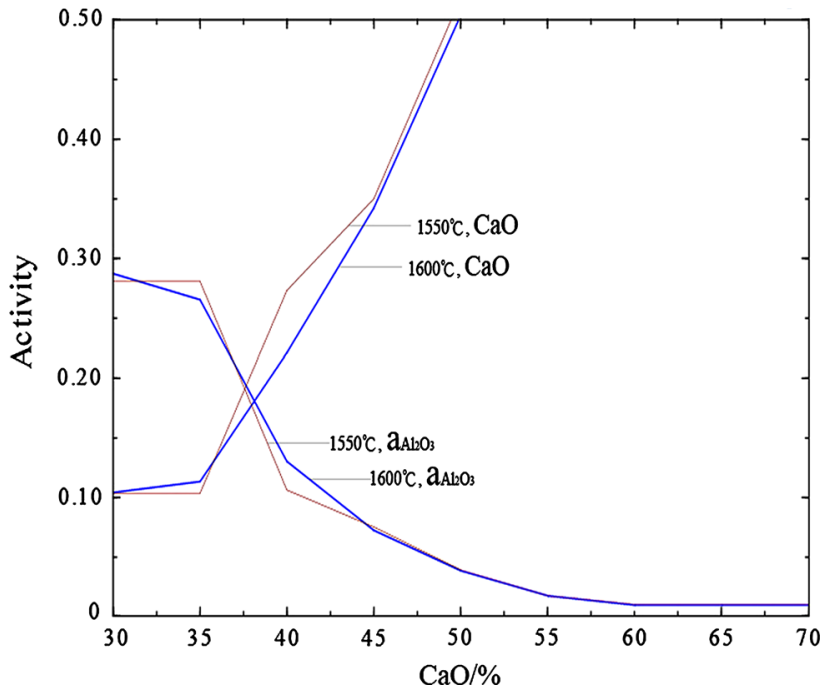

Fig. $3-\mathrm{CaO}$ and $\mathrm{Al}_{2} \mathrm{O}_{3}$ activities in usual range of calcium aluminates at $1823 \mathrm{~K}$ and $1873 \mathrm{~K}\left(1550{ }^{\circ} \mathrm{C}\right.$ and $\left.1600{ }^{\circ} \mathrm{C}\right)$ calculated by FactSage.

Table IV. Activities of $\mathrm{CaO}$ and $\mathrm{Al}_{2} \mathrm{O}_{3}$ in Calcium Aluminates

\begin{tabular}{|c|c|c|c|c|c|c|c|c|}
\hline \multirow[b]{2}{*}{ Mass Pct $\mathrm{CaO}$} & \multicolumn{2}{|c|}{$\begin{array}{c}\text { This work, }[1823 \mathrm{~K} \\
\left.\left(1550{ }^{\circ} \mathrm{C}\right)\right] \text { FactS- } \\
\text { tage }\end{array}$} & \multicolumn{2}{|c|}{$\begin{array}{c}\text { This work, }[1873 \mathrm{~K} \\
\left.\left(1600{ }^{\circ} \mathrm{C}\right)\right] \text { FactS- } \\
\text { tage }\end{array}$} & \multicolumn{2}{|c|}{$\begin{array}{l}\text { Korousic } \\
\text { mun model }\end{array}$} & \multicolumn{2}{|c|}{$\begin{array}{c}\text { Fujisawa }^{[15]} \text { Exper- } \\
\text { iment }\end{array}$} \\
\hline & $a_{\mathrm{CaO}}$ & $a_{\mathrm{Al}_{2} \mathrm{O}_{3}}$ & $a_{\mathrm{CaO}}$ & $a_{\mathrm{Al}_{2} \mathrm{O}_{3}}$ & $a_{\mathrm{CaO}}$ & $a_{\mathrm{Al}_{2} \mathrm{O}_{3}}$ & $a_{\mathrm{CaO}}$ & $a_{\mathrm{Al}_{2} \mathrm{O}_{3}}$ \\
\hline 35 & 0.103 & 0.281 & 0.113 & 0.265 & 0.05 & 0.5 & 0.05 & 0.61 \\
\hline 40 & 0.273 & 0.106 & 0.221 & 0.130 & 0.11 & 0.3 & 0.18 & 0.17 \\
\hline 41 & 0.288 & 0.099 & 0.245 & 0.118 & & & & \\
\hline 42 & 0.304 & 0.093 & 0.269 & 0.107 & & & & \\
\hline 43 & 0.319 & 0.086 & 0.294 & 0.095 & & & & \\
\hline 44 & 0.335 & 0.079 & 0.318 & 0.084 & & & & \\
\hline 45 & 0.350 & 0.075 & 0.342 & 0.072 & 0.14 & 0.13 & 0.30 & 0.08 \\
\hline 46 & 0.384 & 0.068 & 0.374 & 0.079 & & & & \\
\hline 47 & 0.418 & 0.062 & 0.407 & 0.072 & & & & \\
\hline 48 & 0.455 & 0.051 & 0.433 & 0.050 & & & & \\
\hline 49 & 0.489 & 0.044 & 0.472 & 0.043 & & & & \\
\hline 50 & 0.520 & 0.039 & 0.504 & 0.038 & 0.36 & 0.038 & 0.53 & 0.027 \\
\hline 51 & 0.558 & 0.035 & 0.555 & 0.042 & & & & \\
\hline 52 & 0.596 & 0.030 & 0.606 & 0.038 & & & & \\
\hline 53 & 0.635 & 0.026 & 0.658 & 0.034 & & & & \\
\hline 54 & 0.711 & 0.021 & 0.709 & 0.030 & & & & \\
\hline 55 & 0.788 & 0.017 & 0.760 & 0.017 & & & & \\
\hline 56 & 0.829 & 0.015 & 0.806 & 0.013 & 0.6 & 0.012 & 0.72 & 0.02 \\
\hline 57 & 0.870 & 0.012 & 0.853 & 0.012 & & & & \\
\hline 58 & 0.910 & 0.010 & 0.899 & 0.011 & & & & \\
\hline 59 & 0.926 & 0.010 & 0.825 & 0.011 & & & & \\
\hline 60 & 0.945 & 0.010 & 0.942 & 0.010 & & & & \\
\hline 61 & 0.974 & 0.010 & 0.973 & 0.010 & & & & \\
\hline 62 & 0.992 & 0.010 & 0.992 & 0.009 & 1 & 0.005 & 1 & 0.01 \\
\hline
\end{tabular}




\section{INDUSTRIAL TESTS}

The industrial tests were carried out for steel plate cold common (SPCC), a kind of Ca-treated, Al-killed steel during the CSP process in a steel plant in China. Its

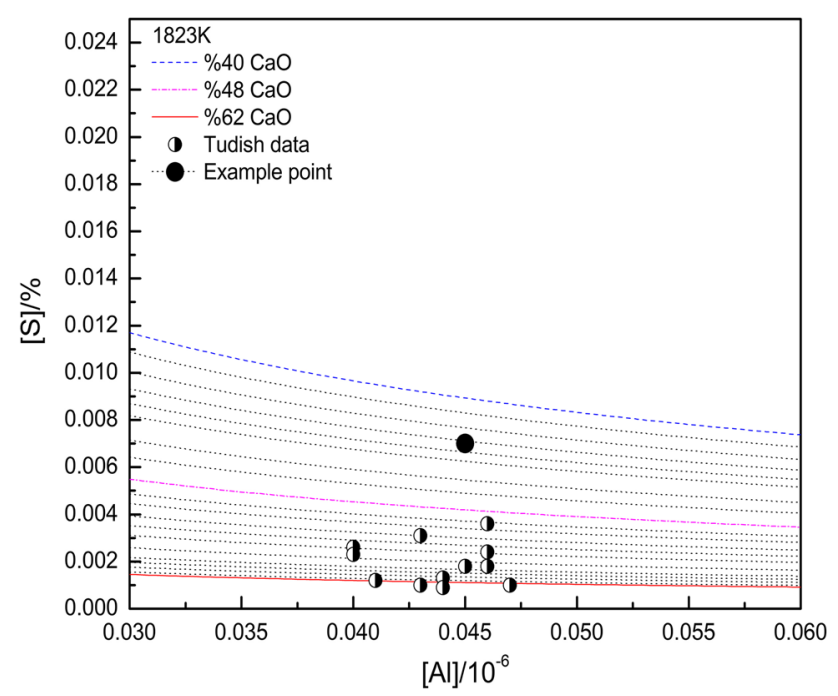

(a)

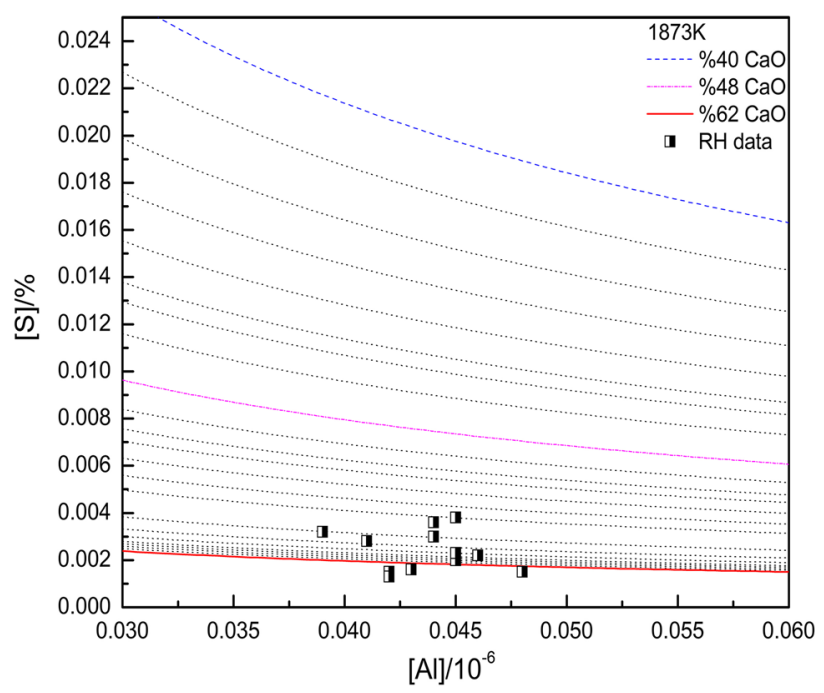

(b)

Fig. 4-Relationship of $\mathrm{Al}$ and $\mathrm{S}$ for precipitation of $\mathrm{CaS}$ in oxide-sulfide duplex inclusions at $1823 \mathrm{~K}$ and $1873 \mathrm{~K}\left(1550{ }^{\circ} \mathrm{C}\right.$ and $1600{ }^{\circ} \mathrm{C}$ ). (a) Relationship of $\mathrm{Al}$ and $\mathrm{S}$ for precipitation of $\mathrm{CaS}$ in oxide-sulfide duplex inclusions at $1823 \mathrm{~K}\left(1550{ }^{\circ} \mathrm{C}\right)$. (b) Relationship of $\mathrm{Al}$ and $\mathrm{S}$ for precipitation of $\mathrm{CaS}$ in oxide-sulfide duplex inclusions at $1873 \mathrm{~K}\left(1600{ }^{\circ} \mathrm{C}\right)$.
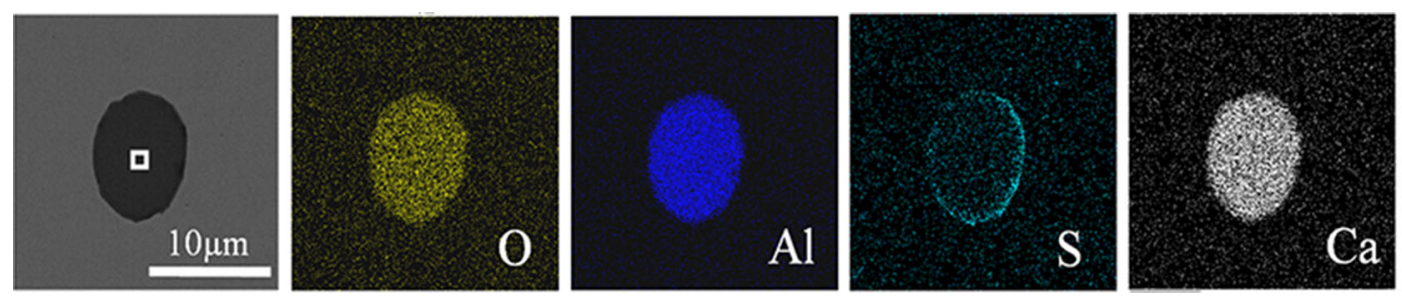

$\mathrm{Al}_{2} \mathrm{O}_{3}: 49.05$

$\operatorname{mass} \%$

$\mathrm{CaO}: 50.95$

Fig. 5-SEM mapping of oxide-sulfur duplex inclusion in steel sample of tundish. 
Table V. Standard Gibbs Free Energy of Reaction in Process of Calcium Treatment ${ }^{[4,16]}$

\begin{tabular}{ll}
\hline Reaction & \multicolumn{1}{c}{$\Delta G^{\circ} / \mathrm{J} \mathrm{mol}^{-1}$} \\
\hline $3[\mathrm{Ca}]+\mathrm{Al}_{2} \mathrm{O}_{3}=3 \mathrm{CaO}+2[\mathrm{Al}]$ & $-664,577+40.45 \mathrm{~T}$ \\
$\mathrm{CaO}+\mathrm{Al}_{2} \mathrm{O}_{3}=\mathrm{CaO} \cdot \mathrm{Al}_{2} \mathrm{O}_{3}$ & $-18,000-18.83 \mathrm{~T}$ \\
$12 \mathrm{CaO}+7 \mathrm{Al}_{2} \mathrm{O}_{3}=12 \mathrm{CaO} \cdot 7 \mathrm{Al}_{2} \mathrm{O}_{3}$ & $-73,053-207.53 \mathrm{~T}$ \\
$3 \mathrm{CaO}+\mathrm{Al}_{2} \mathrm{O}_{3}=3 \mathrm{CaO} \cdot \mathrm{Al}_{2} \mathrm{O}_{3}$ & $-12,600-24.69 \mathrm{~T}$ \\
\hline
\end{tabular}

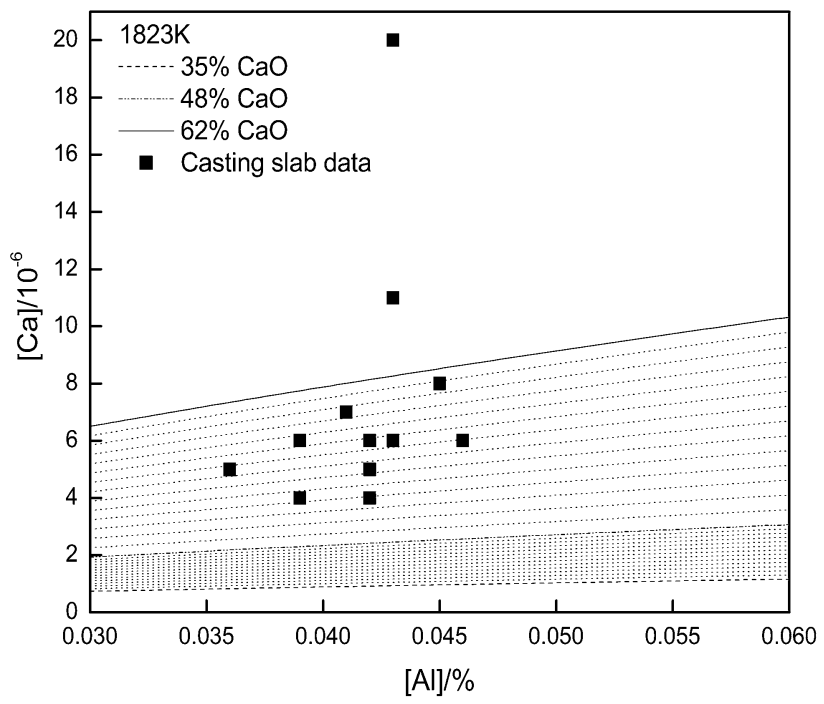

(a)

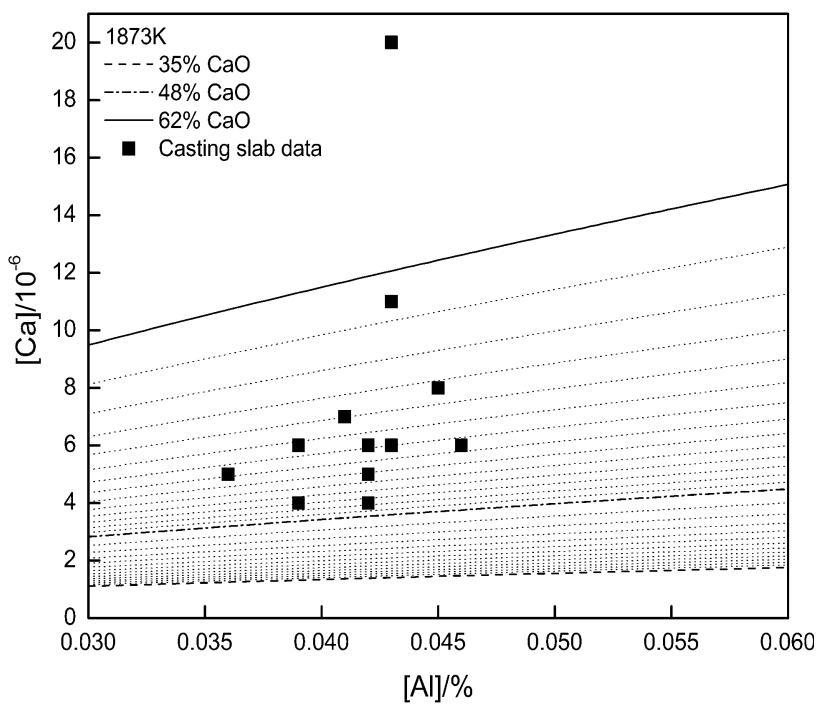

(b)

Fig. 6-Relationship between $\mathrm{Ca}$ and $\mathrm{Al}$ of different calcium aluminates at $1823 \mathrm{~K}$ and $1873 \mathrm{~K}\left(1550{ }^{\circ} \mathrm{C}\right.$ and $\left.1600{ }^{\circ} \mathrm{C}\right)$. (a) Relationship between $\mathrm{Ca}$ and $\mathrm{Al}$ of different calcium aluminates at $1823 \mathrm{~K}$ $\left(1550{ }^{\circ} \mathrm{C}\right)$. (b) Relationship between $\mathrm{Ca}$ and $\mathrm{Al}$ of different calcium aluminates at $1873 \mathrm{~K}\left(1600{ }^{\circ} \mathrm{C}\right)$.

precipitation of $\mathrm{CaS}$, thermodynamic analysis was performed at $1823 \mathrm{~K}$ and $1873 \mathrm{~K}\left(1550{ }^{\circ} \mathrm{C}\right.$ and $\left.1600{ }^{\circ} \mathrm{C}\right)$ for comparison:

$$
\lg f_{\mathrm{i}}=\sum e_{i}^{j}[\operatorname{Pct} j]
$$

Table VI. Physical Properties of Inclusions ${ }^{[18]}$

\begin{tabular}{lccc}
\hline Inclusion & Density $\left(\mathrm{g} \mathrm{cm}^{-3}\right)$ & $\begin{array}{c}\text { Melting point } \\
{\left[\mathrm{K}\left({ }^{\circ} \mathrm{C}\right)\right]}\end{array}$ & $\begin{array}{c}\text { Microhardness } \\
\left(\mathrm{kg} \mathrm{mm}^{-2}\right)\end{array}$ \\
\hline $\mathrm{Al}_{2} \mathrm{O}_{3}$ & 3.96 & $2325(2052)$ & 3750 \\
$\mathrm{CA}_{6}$ & 3.28 & $2123(1850)$ & 2200 \\
$\mathrm{CA}_{2}$ & 2.91 & $2023(1750)$ & 1100 \\
$\mathrm{CA}$ & 2.98 & $1878(1605)$ & 930 \\
$\mathrm{C}_{12} \mathrm{~A}_{7}$ & 2.83 & $1728(1455)$ & - \\
$\mathrm{C}_{3} \mathrm{~A}$ & 3.04 & $1808(1535)$ & - \\
$\mathrm{CaO}$ & 3.34 & $2843(2570)$ & 400 \\
$\mathrm{CaS}$ & 2.50 & $2723(2450)$ & - \\
\hline
\end{tabular}

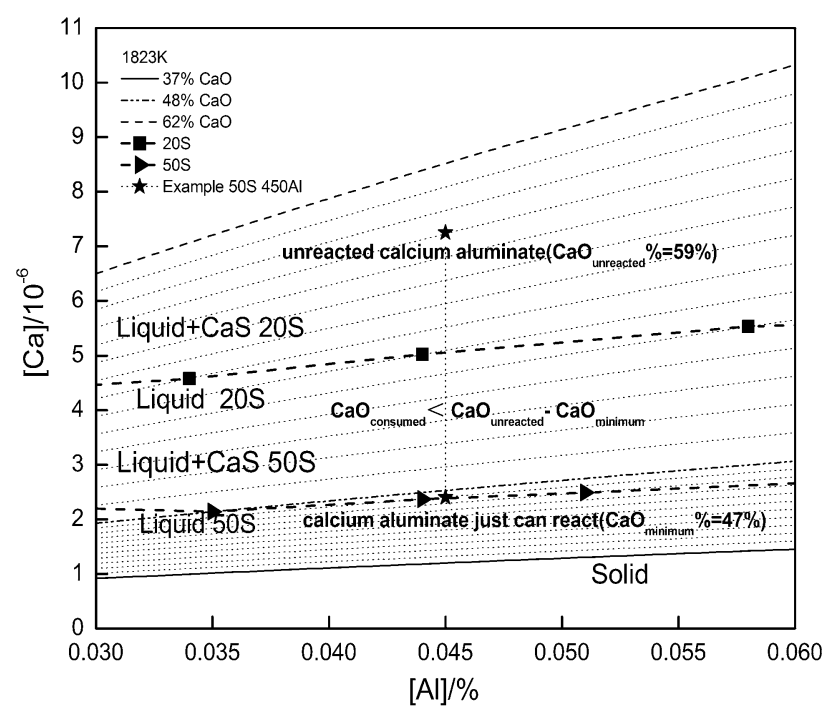

(a)

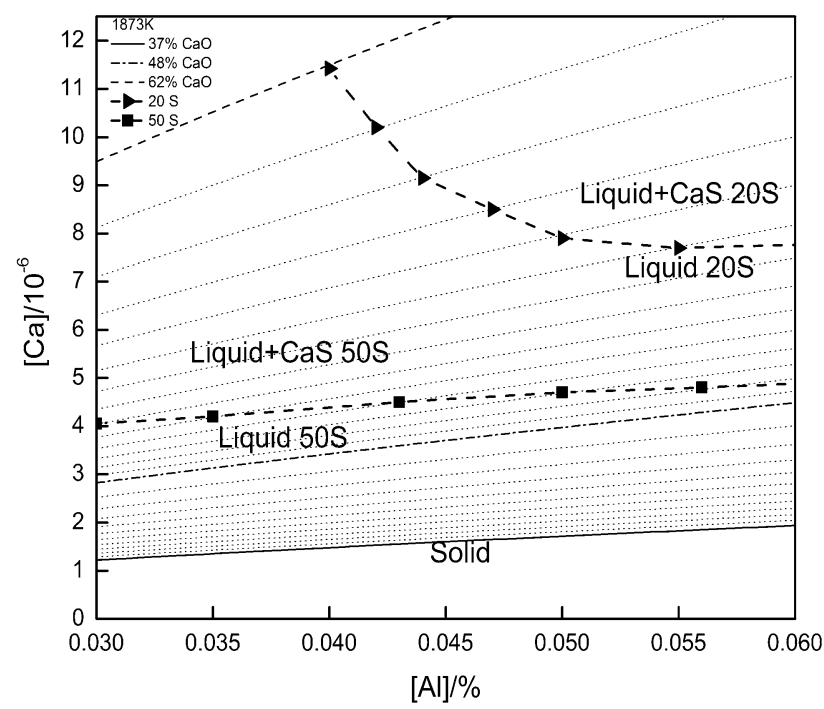

(b)

Fig. 7-Precipitated area of oxide-sulfide duplex inclusion when sulfur content is 20 and $50 \mathrm{ppm}$, respectively, at $1823 \mathrm{~K}$ and $1873 \mathrm{~K}$ $\left(1550{ }^{\circ} \mathrm{C}\right.$ and $\left.1600{ }^{\circ} \mathrm{C}\right)$. (a) Precipitated area of oxide-sulfide duplex inclusion when sulfur content is 20 and $50 \mathrm{ppm}$ at $1823 \mathrm{~K}\left(1550^{\circ} \mathrm{C}\right)$. (b) Precipitated area of oxide-sulfide duplex inclusion when sulfur content is 20 and $50 \mathrm{ppm}$ at $1873 \mathrm{~K}\left(1600{ }^{\circ} \mathrm{C}\right)$. 
Figure 1 shows the relationship between $\mathrm{Ca}$ and $\mathrm{S}$ for the precipitation of $\mathrm{CaS}$ at $1823 \mathrm{~K}$ and $1873 \mathrm{~K}\left(1550{ }^{\circ} \mathrm{C}\right.$ and $1600{ }^{\circ} \mathrm{C}$ ). It was calculated by Eq. [2] and $a_{\mathrm{CaS}}$ was considered to be 1 relative to the pure solid standard. From Figure 1, it can be seen that the lower temperature, the easier it is to precipitate $\mathrm{CaS}$. $\mathrm{CaS}$ cannot precipitate at $1873 \mathrm{~K}\left(1600{ }^{\circ} \mathrm{C}\right)$, and it more likely precipitates after the formation of calcium aluminates due to precipitation of $\mathrm{CaS}$ that needs a lower temperature.

Figure 2 shows SEM mapping of a special inclusion in which $\mathrm{CaS}$ was wrapped by calcium aluminates in steel samples after calcium treatment. Perhaps because of the high content of $\mathrm{Ca}$ and $\mathrm{S}$ in a small part of the molten steel after calcium treatment, Ca reacted directly with $\mathrm{S}$ precipitating $\mathrm{CaS}$ and then it was wrapped by calcium aluminates that formed later. It may prove that which forms first will be wrapped by the other between $\mathrm{CaS}$ and calcium aluminate. In the industrial tests, $\mathrm{CaS}$ were always found in the outer calcium aluminates and it may be because CaS precipitates after the formation of calcium aluminates due to its need for lower temperature. This matches with the thermodynamic calculation.

Due to the high activity of $\mathrm{CaO}$ in complete or overmodified calcium aluminates, $\mathrm{CaO}$ can react with dissolved $\mathrm{Al}, \mathrm{S}$ in steel forming $\mathrm{CaS}$ and $\mathrm{Al}_{2} \mathrm{O}_{3}$. The chemical reaction is expressed as ${ }^{[2]}$ :

$$
\begin{gathered}
3 \mathrm{CaO}+2[\mathrm{Al}]+3[\mathrm{~S}]=3 \mathrm{CaS}+\mathrm{Al}_{2} \mathrm{O}_{3} \\
\Delta G_{2}^{\circ}=-879760+298.73 T
\end{gathered}
$$

Thus, the mass fraction relationship between $\mathrm{Al}$ and $\mathrm{S}$ for the oxide-sulfide duplex inclusion is as follows:

$$
[\text { mass pct Al }]^{2}[\text { mass pct }]^{3}=\exp \left(-\frac{\Delta G_{2}^{\circ}}{\mathrm{RT}}\right) \frac{a_{\mathrm{CaS}}^{3} a_{\mathrm{Al}_{2} \mathrm{O}_{3}}}{a_{\mathrm{CaO}}^{3} f_{\mathrm{S}}^{\beta} f_{\mathrm{Al}}^{2}}
$$

Since there are not enough available experimental data, the thermodynamic software FactSage was used for estimating the activities of $\mathrm{CaO}$ and $\mathrm{Al}_{2} \mathrm{O}_{3}$ in calcium aluminates, and Figure 3 shows the results of calculation by FactSage. Table IV allows for the comparison from this work and previous researches. The calculated activities are in good agreement with the experimental value of Fujisawa. ${ }^{[15]}$ The activities of $\mathrm{CaO}$ and $\mathrm{Al}_{2} \mathrm{O}_{3}$ of other calcium aluminates used in this thermodynamic analysis are also listed in Table IV. $a_{\mathrm{CaS}}$ was considered to be 1 relative to the pure solid standard.

Figure 4 shows the relationship between $\mathrm{Al}$ and $\mathrm{S}$ for the precipitation of $\mathrm{CaS}$ with various calcium aluminates at $1823 \mathrm{~K}$ and $1873 \mathrm{~K}\left(1550{ }^{\circ} \mathrm{C}\right.$ and $\left.1600^{\circ} \mathrm{C}\right)$. The curves were calculated by Eq. [5]. In particular, more calcium aluminates were considered in Al-S equilibrium and the calculation became more accurate. For example, in Figure 4(a), other researchers ${ }^{[2,4,5]}$ may consider that $\mathrm{CaS}$ will precipitate when $\mathrm{Al}$ is 0.045 pct and $\mathrm{S}$ reaches about 0.0045 pct for the example point. But in this article, with the same example point, when $\mathrm{Al}$ is 0.045 pct, $\mathrm{CaS}$ cannot precipitate until $\mathrm{S}$ reaches $0.0072 \mathrm{pct}$ at least. It can be seen that the lower temperature, the easier it is to precipitate $\mathrm{CaS}$-bearing inclusion from the comparison between (a) and (b) of Figure 4. In addition, $\mathrm{Al}$ has little effect on the precipitation of CaS-bearing inclusion, whereas $\mathrm{S}$ strongly influences the precipitation of CaS-bearing inclusion. The possibility of precipitating $\mathrm{CaS}$ increases with $\mathrm{S}$ content. Oxide-sulfur duplex inclusion is shown in Figure 5, and its characteristic is that $\mathrm{CaO}, \mathrm{Al}_{2} \mathrm{O}_{3}$, and $\mathrm{CaS}$ mix in the outer layer of calcium aluminate inclusion.

For establishing the precipitation-area diagram of oxide-sulfide duplex inclusion, the process of calcium treatment was also researched. Because dissolved oxygen is very low in Al-killed steel when $\mathrm{Ca}$ is added to the liquid steel, the direct reaction between calcium and dissolved oxygen is deemed to be very few and it is ignored in this article. Thus, calcium treatment can be described by the following sets of chemical reactions:

$$
\begin{gathered}
x[\mathrm{Ca}]+x / 3 \mathrm{Al}_{2} \mathrm{O}_{3}=x \mathrm{CaO}+2 / 3 x[\mathrm{Al}] \text { where } 0<x \leq 1 \\
\quad x \mathrm{CaO}+(1-x) \mathrm{Al}_{2} \mathrm{O}_{3}=(\mathrm{CaO})_{x}\left(\mathrm{Al}_{2} \mathrm{O}_{3}\right)_{1-x} \\
\quad \text { where } 0<x \leq 1
\end{gathered}
$$

Rearrangement of Eqs. [6] and [7] yields the following reaction:

$$
\begin{aligned}
x[\mathrm{Ca}]+\left(1-\frac{2}{3} x\right) \mathrm{Al}_{2} \mathrm{O}_{3}= & (\mathrm{CaO})_{x}\left(\mathrm{Al}_{2} \mathrm{O}_{3}\right)_{1-x} \\
& +\frac{2}{3} x[\mathrm{Al}] \quad \text { where } 0<x \leq 1
\end{aligned}
$$

The standard Gibbs free energy of Eq. [8] can be calculated by the data of Table $\mathrm{V}$ according to a specific response. $a_{(\mathrm{CaO})_{x}\left(\mathrm{Al}_{2} \mathrm{O}_{3}\right)_{1-x}}$ and $a_{\mathrm{Al}_{2} \mathrm{O}_{3}}$ were considered to be 1 using a pure substance as the standard state, so the mass fraction relationship between $\mathrm{Ca}$ and $\mathrm{Al}$ is as follows:

$$
[\mathrm{Al} \text { pct }]^{\frac{2}{3} x} /[\mathrm{Ca} \mathrm{pct}]^{x}=\exp \left(-\Delta G_{3}^{\circ} / \mathrm{RT}\right) \frac{f_{\mathrm{Ca}}^{x}}{f_{\mathrm{Al}}^{\frac{2}{3}}}
$$

Figure 6 shows $\mathrm{Ca}-\mathrm{Al}$ equilibrium with various calcium aluminates in which the mass fraction of $\mathrm{CaO}$ occupy 35 to 62 pct at $1823 \mathrm{~K}$ and $1873 \mathrm{~K}\left(1550{ }^{\circ} \mathrm{C}\right.$ and $1600^{\circ} \mathrm{C}$ ). The curves of $\mathrm{CA}, \mathrm{C}_{12} \mathrm{~A}_{7}$, and $\mathrm{C}_{3} \mathrm{~A}$ were calculated by Eq. [9]. Other curves of calcium aluminates were calculated by adding the curves of $\mathrm{CA}$, $\mathrm{C}_{12} \mathrm{~A}_{7}$, and $\mathrm{C}_{3} \mathrm{~A}$ in proportion.

It needs about 40 minutes for the reaction of calcium treatment to reach equilibrium under the condition of having slag. ${ }^{[17]}$ So the contents of $\mathrm{Ca}$ and $\mathrm{Al}$ at tundish station (as shown in Figure 6(b)) do not agree with the thermodynamic calculation at $1873 \mathrm{~K}\left(1600^{\circ} \mathrm{C}\right)$ because the equilibrium time is not enough. In 
consideration of dissolved $\mathrm{Ca}$, the content is lower than that of total $\mathrm{Ca}$, and the thermodynamic calculation of $\mathrm{Ca}-\mathrm{Al}$ equilibrium at $1823 \mathrm{~K}\left(1550{ }^{\circ} \mathrm{C}\right)$ agrees well with stable C-A-S layer at last. So, the mass fraction of $\mathrm{CaS}$ in the stable C-A-S layer can be estimated and predicted by Eq. [10]:

$$
\mathrm{CaS} \text { pct }=\frac{\mathrm{CaS}_{\text {generated }} \text { pct }}{\left(\mathrm{CaO}_{\text {unreacted }} \text { pct }-\mathrm{CaO}_{\text {consumed }} \text { pct }\right)+\left(\mathrm{Al}_{2} \mathrm{O}_{3_{\text {unreacted }}} \text { pct }+\mathrm{Al}_{2} \mathrm{O}_{3_{\text {generated }}} \text { pct }\right)+\mathrm{CaS}_{\text {generated }} \text { pct }}
$$

the test data (as shown in Figure 6(a)) because the equilibrium time (10 minutes at RH and 30 minutes at tundish) for calcium treatment is enough.

$\mathrm{Ca}-\mathrm{Al}$ equilibrium and Al-S equilibrium can be reached at the same time; therefore, $\mathrm{Ca}-\mathrm{Al}$ equilibrium and Al-S equilibrium were combined in this article. In Figure 4, by fixing sulfur content at 20 and $50 \mathrm{ppm}$ respectively, several intersections can be achieved on partial Al-S equilibrium curves. Then plugging these intersections into the corresponding $\mathrm{Ca}-\mathrm{Al}$ equilibrium curves in Figure 6 and connecting the dots, the area above the line is the precipitated area of oxide-sulfide duplex inclusion and the area below the line is the area of liquid calcium aluminates. Figure 7 was obtained by this method.

Figure 7 shows the precipitation area of oxide-sulfide duplex inclusion at $1823 \mathrm{~K}$ and $1873 \mathrm{~K}\left(1550{ }^{\circ} \mathrm{C}\right.$ and
The example in Figure 7(a) shows the meanings of $\mathrm{CaO}_{\text {unreacted }}$ pct, $\mathrm{CaO}_{\text {consumed }}$ pct, and $\mathrm{CaO}_{\text {minimum }}$ pct. Specifically, $\mathrm{CaO}_{\text {consumed }}$ pet is mass fraction of $\mathrm{CaO}$, which is consumed in Reaction [4] and $\mathrm{CaS}_{\text {generated }}$ pct is the mass fraction of $\mathrm{CaS}$, which is generated in Reaction [4]. $\mathrm{CaO}_{\text {unreacted }}$ pct is the mass fraction of $\mathrm{CaO}$ in calcium aluminate, which is about to begin to react with [Al] and [S]. The meanings of the subscripts of $\mathrm{Al}_{2} \mathrm{O}_{3}$ in Eq. [10] are the same with corresponding subscripts of $\mathrm{CaO}$ and $\mathrm{CaS}$. According to the mass balance relationship of Reaction [4], $\mathrm{CaS}_{\text {generated }}$ pct equals $1.29 \mathrm{CaO}_{\text {consumed }}$ pct and $\mathrm{Al}_{2} \mathrm{O}_{3 \text { generated }}$ pct equals $0.61 \mathrm{CaO}_{\text {consumed }}$ pct. Since the quantity of $\mathrm{CaS}$ that is generated in Reaction [4] is small, and for the ease of calculation, $\mathrm{CaS}$ is considered to be $\mathrm{Al}_{2} \mathrm{O}_{3}$ when calculating the mass fraction or activity of $\mathrm{CaO}$ in the $\mathrm{CaO}-\mathrm{Al}_{2} \mathrm{O}_{3}-\mathrm{CaS}$ system:

$$
\begin{array}{r}
\mathrm{CaO}_{\text {minimum }} \text { pct }=\frac{\mathrm{CaO}_{\text {unreacted }} \text { pct }-\mathrm{CaO}_{\text {consumed }} \text { pct }}{\left(\mathrm{CaO}_{\text {unreacted }} \text { pct }-\mathrm{CaO}_{\text {consumed }} \text { pct }\right)+\left(\mathrm{Al}_{2} \mathrm{O}_{3_{\text {unreacted }}} \text { pct }+\mathrm{Al}_{2} \mathrm{O}_{3_{\text {generated }}} \text { pct }\right)+\mathrm{CaS}_{\text {generated }} \text { pct }} \\
\text { where } \mathrm{CaO}_{\text {initial }} \text { pct }+\mathrm{Al}_{2} \mathrm{O}_{3 \text { initial }} \text { pct }=1
\end{array}
$$

$\left.1600{ }^{\circ} \mathrm{C}\right)$. It is observed that both $\mathrm{S}$ content and the temperature have significant impact on the precipitation of $\mathrm{CaS}$. The lower the temperature and the higher the $\mathrm{S}$ content, the easier it is to precipitate oxide-sulfide duplex inclusion.

Figure 8 shows an unreacted core model of evolution of the $\mathrm{CaO}-\mathrm{Al}_{2} \mathrm{O}_{3}$ system into the $\mathrm{CaO}-\mathrm{Al}_{2} \mathrm{O}_{3}-\mathrm{CaS}$ system. In Figure 8, the Reaction [4] in the reacting layer continues until $\mathrm{CaO}$ in the layer cannot react with [Al] and [S] from the liquid steel. The C-A-S layer is a stable layer, and it cannot react with [Al] and [S] again assuming $\mathrm{S}$ and $\mathrm{Al}$ contents in the liquid steel do not change in the process of Reaction [4]. In addition, it is deemed that $\mathrm{CaO}, \mathrm{Al}_{2} \mathrm{O}_{3}$, and $\mathrm{CaS}$ cannot diffuse in the whole inclusion due to concentration difference, which means they are all still in the process of Reaction [4]. In the model, unreacted $\mathrm{CaO}$ and $\mathrm{Al}_{2} \mathrm{O}_{3}$ of calcium aluminates that involved Reaction [4] as well as $\mathrm{CaS}$ and $\mathrm{Al}_{2} \mathrm{O}_{3}$, which generated in Reaction [4] make up the
$\mathrm{CaO}_{\text {minimum }}$ pet can be known in Figure 7, and it is the minimum mass fraction of $\mathrm{CaO}$ in calcium aluminate that can react with $[\mathrm{Al}]$ and $[\mathrm{S}]$. Rearrangement of Eqs. [10] and [11] yields Eq. [12]:

$$
\mathrm{CaS} \text { pct }=\frac{1.29\left(\mathrm{CaO}_{\text {unreacted }} \text { pct }-\mathrm{CaO}_{\text {minimum }} \text { pct }\right)}{1+0.9 \mathrm{CaO}_{\text {initial }} \text { pct }}
$$

Figure 9 shows the CaS capacity for certain calcium aluminates under the condition of fixing the content of $\mathrm{Al}$ and $\mathrm{S}$. Figure 9 was calculated by Eq. [12]. The results of the calculation are coordinated with the test results of the inclusion (as shown in Figures 10 and 11). Although the quantity of generated $\mathrm{CaS}$ is not much, $\mathrm{CaS}$ has a significant effect on the physicochemical property of $\mathrm{CaO}$ $\mathrm{Al}_{2} \mathrm{O}_{3}-\mathrm{CaS}$ inclusion. This will be explained in the following section. 


\section{B. Deformation During Rolling}

Figure 10 shows a series of calcium aluminates wrapped by pure $\mathrm{CaS}$ or oxide-sulfide duplex inclusion and their rolling directions toward right uniformly. Groups (a) to (d) in Figure 10 show deformation of A-CA ${ }_{6}-\mathrm{CA}_{2}-\mathrm{CA}$ wrapped by pure $\mathrm{CaS}$. In group (a) of Figure 10, due to the high melting point and high microhardness of $\mathrm{Al}_{2} \mathrm{O}_{3}$ (as shown in Table VI), no deformation occurs during the rolling process.The $\mathrm{CaS}$ layer of it was torn but not separated from the $\mathrm{Al}_{2} \mathrm{O}_{3}$ core. In group (b) of Figure 10, which is similar to group (a), the CaS layer was torn. But there is a little difference, a small angle of the inclusion was stripped. It may because the microhardness of $\mathrm{CA}_{6}$ (as shown in Table $\mathrm{V}$ ) is lower than $\mathrm{Al}_{2} \mathrm{O}_{3}$ and the microhardness is not enough to make the whole inclusion keep from being not broken. If the microhardness of the inclusion core falls further and the plasticity of the inclusion core is not enough, the whole inclusion may be crushed down during the rolling process. As expected, the inclusion of $\mathrm{CA}_{2}$ wrapped by $\mathrm{CaS}$ was crushed down (as shown in group (c1) of Figure 10) due to its lower microhardness and insufficient plasticity. But when the pure CaS layer becomes thicker, it can prevent $\mathrm{CA}_{2}$ from being crushed (as shown in group (c2) of Figure 10). With the decreasing of the microhardness, the plasticity of the inclusion will increase, and when it increases to some extent, the inclusion will have a certain deformation ability to protect itself against the pressure and shear stress generated during the rolling process. In group (d) in Figure 10, the inclusion of $\mathrm{CA}$ wrapped by $\mathrm{CaS}$ deformed slightly and produced a pointed tail because of the deformation. This illustrates that the inclusion of $\mathrm{CA}$ wrapped by $\mathrm{CaS}$ has a certain plastic yielding ability. The CaS layer of the inclusion was not broken possibly because deformation of the CA core decreased the impact force. The melting point of $\mathrm{CA}$ is about $1873 \mathrm{~K}\left(1600{ }^{\circ} \mathrm{C}\right)$, and it can be a demarcation point of

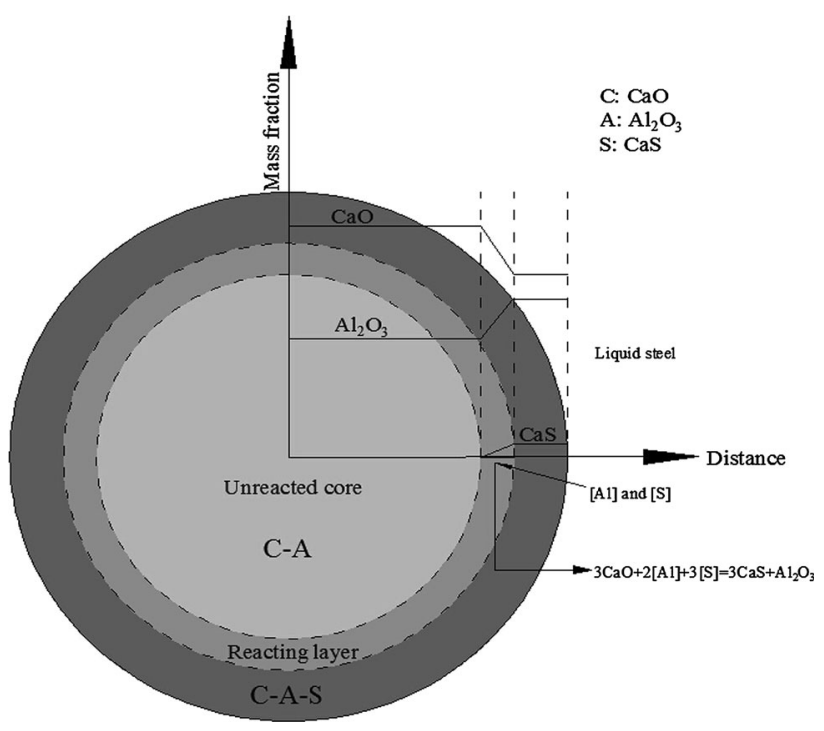

Fig. 8-Unreacted core model of evolution of $\mathrm{CaO}-\mathrm{Al}_{2} \mathrm{O}_{3}$ system into $\mathrm{CaO}-\mathrm{Al}_{2} \mathrm{O}_{3}-\mathrm{CaS}$ system. beginning to have a plastic yielding ability for calcium aluminates. In group (e) in Figure 10, the shell of the inclusion is oxide-sulfide duplex inclusion and the composition of the inclusion core is close to $\mathrm{C}_{12} \mathrm{~A}_{7}$. It can be seen that both the shell and the core of the inclusion had a strong plastic yielding ability and almost deform uniformly. In general, the melting point has a corresponding relation to plastic yielding ability for the same kind of inclusion. The lower the melting point, the better deformation performance the inclusion has. The melting point of the calcium aluminates core is about $1500 \mathrm{~K}\left(1227^{\circ} \mathrm{C}\right)$ lower than $1873 \mathrm{~K}\left(1600{ }^{\circ} \mathrm{C}\right)$ and that of the shell is about $1800 \mathrm{~K}\left(1527^{\circ} \mathrm{C}\right)$. So the core should have plastic yielding ability and the shell did not prevent its plastic deformation. In oxide-sulfide duplex inclusion, the melting point of the shell is always higher than the core because of the joining of $\mathrm{CaS}$. So if $\mathrm{CaS}$ in the oxide-sulfide duplex shell becomes more, the shell may prevent the plastic deformation of the whole inclusion. In group (f) in Figure 10, the shell of the inclusion is also oxide-sulfide duplex inclusion and composition of the inclusion core is close to $\mathrm{C}_{2} \mathrm{~A}$. The inclusion is no plastic deformation. The melting point of the core is about $1673 \mathrm{~K}\left(1400{ }^{\circ} \mathrm{C}\right)$ lower than $1873 \mathrm{~K}$ $\left(1600{ }^{\circ} \mathrm{C}\right)$ and that of the shell is about $1910 \mathrm{~K}$ $\left(1637^{\circ} \mathrm{C}\right)$. Because of the high melting point of the shell and plastic deformation ability of the core, it can be believed that the shell prevents the plastic yielding of the whole inclusion. Oxide-sulfide duplex shells like (e) and (f) type of shells were located in the $\mathrm{CaO}-\mathrm{Al}_{2} \mathrm{O}_{3}-\mathrm{CaS}$ isothermal section calculated by Factsage (as shown in Figure 11). It can be found that there is a clear dividing line between the two kinds of shell. According to this line and the corresponding relation between melting point and plastic deformation, the plastic deformation region of oxide-sulfide duplex inclusion was roughly confirmed. Zone (1) in Figure 11 can be the plastic deformation region. It can be seen that $\mathrm{CaS}$ has a

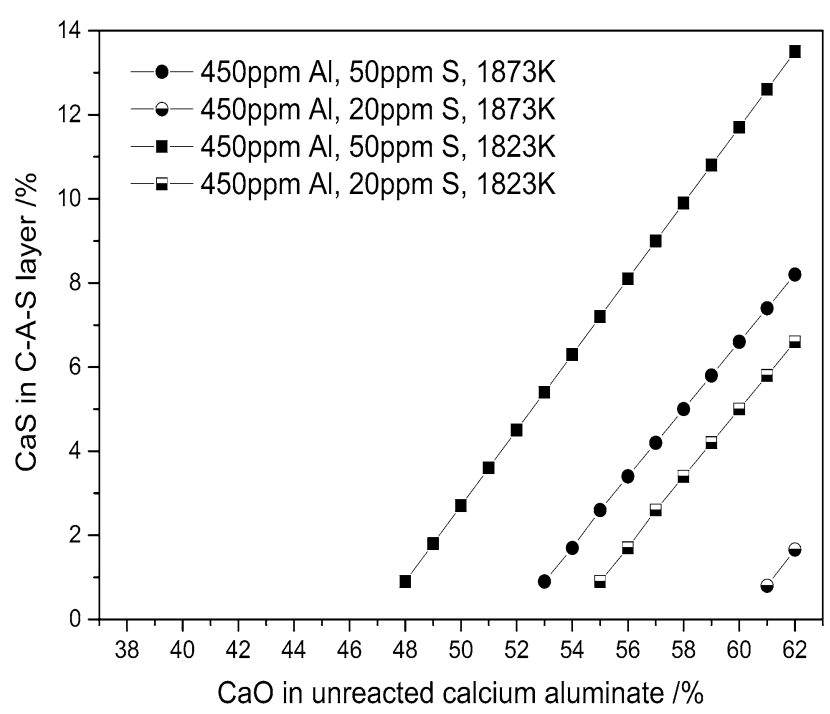

Fig. 9-Mass fraction of $\mathrm{CaS}$ in $\mathrm{CaO}-\mathrm{Al}_{2} \mathrm{O}_{3}-\mathrm{CaS}$ inclusions when Reaction [4] reach equilibrium under different conditions. 

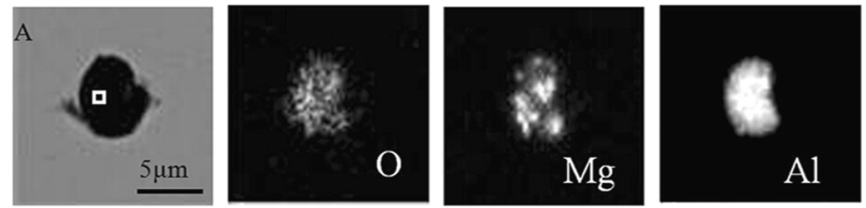

(a)
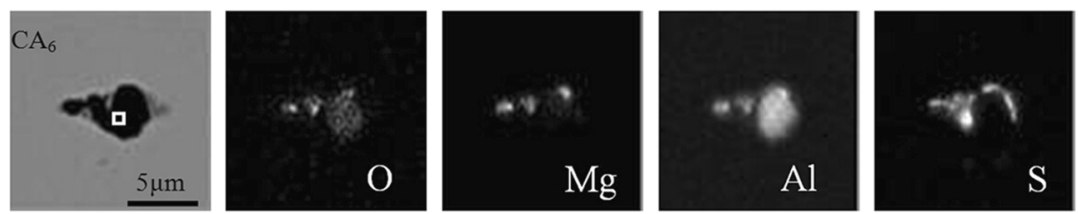

(b)
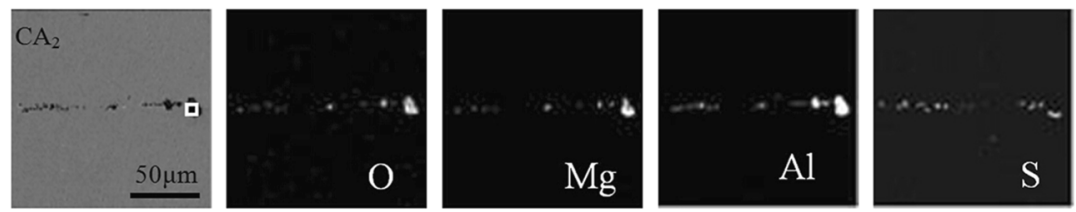

(c1)
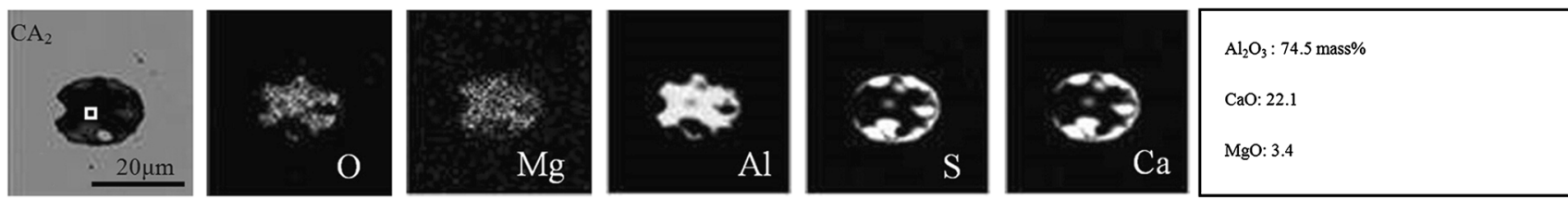

(c2)
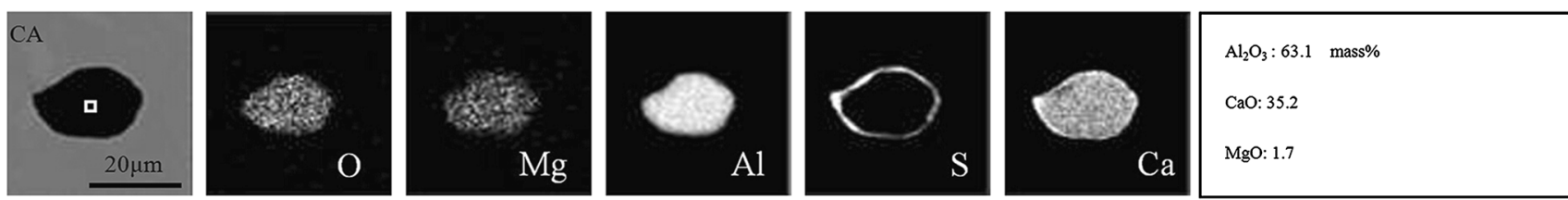

(d)
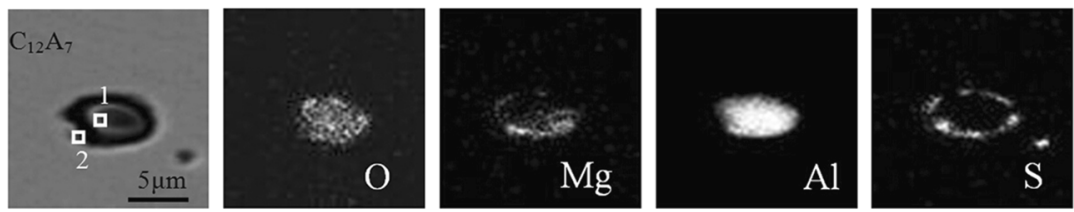

(e)
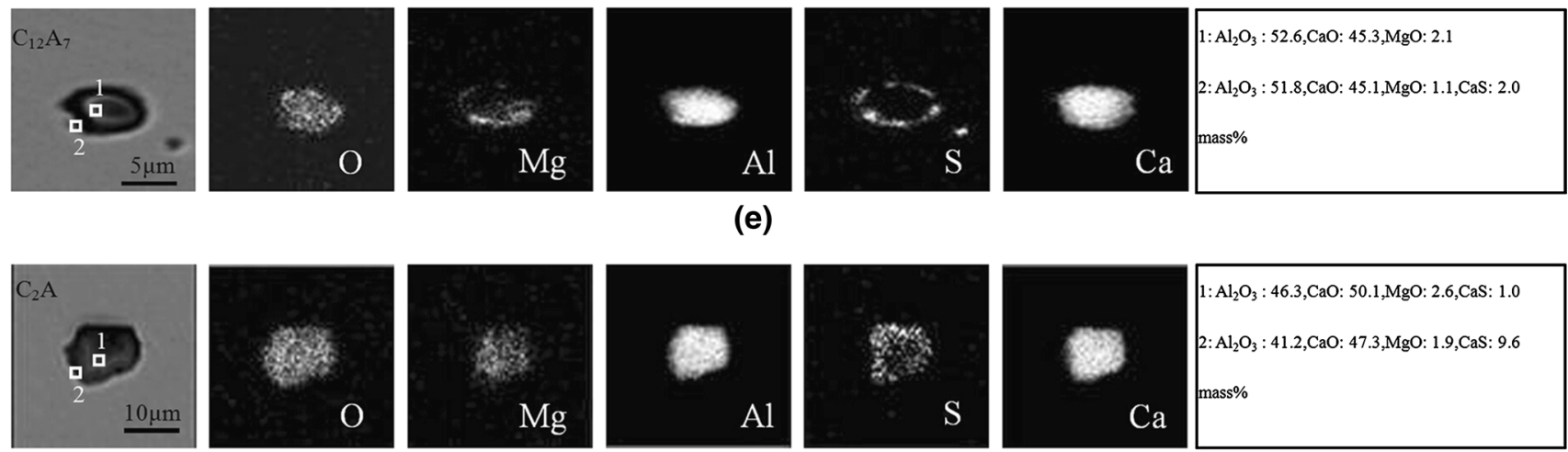

(f)

Fig. 10 -EPMA mapping of CaS-bearing inclusions. (a) EPMA mapping of A wrapped by CaS. (b) EPMA mapping of CA 6 wrapped by CaS. (cl) EPMA mapping of $\mathrm{CA}_{2}$ wrapped by CaS. (c2) EPMA mapping of $\mathrm{CA}_{2}$ wrapped by CaS. (d) EPMA mapping of CA wrapped by CaS. (e) EPMA mapping of $\mathrm{C}_{12} \mathrm{~A}_{7}$ wrapped by oxide-sulfide duplex inclusion. (f) EPMA-mapping of $\mathrm{C}_{2} \mathrm{~A}$ wrapped by oxide-sulfide duplex inclusion.

significant influence on the melting point and plastic deformation ability of the oxide-sulfide duplex inclusion. A small quantity of CaS may make the oxide-sulfide duplex shell lose plastic deformation ability due to the mushroom of the melting point.
By summarizing this inclusion observation, the process of calcium treatment is a softening process of modified inclusion. With the core of CaS-bearing inclusions changing in $\mathrm{A}-\mathrm{CA}_{6}-\mathrm{CA}_{2}-\mathrm{CA}-\mathrm{C}_{12} \mathrm{~A}_{7}$ or $\mathrm{C}_{2} \mathrm{~A}$, the deformation of the inclusions core varies with a route of no 


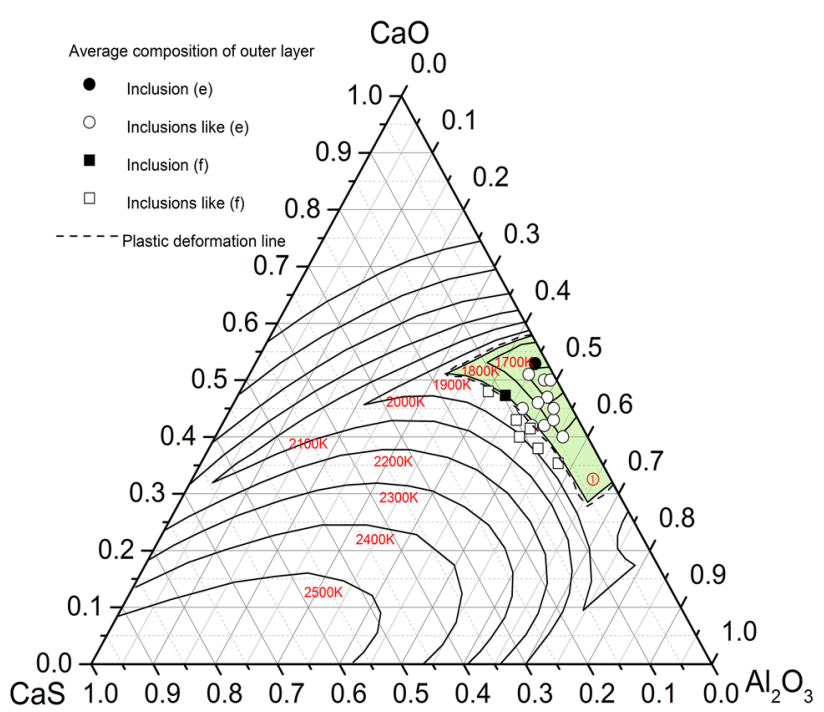

Fig. $11-\mathrm{CaO}-\mathrm{Al}_{2} \mathrm{O}_{3}-\mathrm{CaS}$ isothermal section diagram.

deformation-low brittleness-brittleness-little deformation-plastic deformation. But when these calcium aluminates are wrapped by pure $\mathrm{CaS}$ or oxide-sulfide duplex shell, their deformation ability may change. The deformations of low-modified calcium aluminates wrapped by pure $\mathrm{CaS}$ have different degrees of harm. A pure $\mathrm{CaS}$ layer, especially the thick one, has some protective and cushioning effect to calcium aluminates. An oxide-sulfide duplex shell contains less $\mathrm{CaS}$ and does not prevent plastic yielding of whole inclusion. When an oxide-sulfide duplex shell contains more $\mathrm{CaS}$ in the outer layer, it will lose the plastic yielding ability and even prevent the plastic deformation of whole oxide-sulfide duplex inclusion due to its high melting point. Therefore, it is important to modify $\mathrm{Al}_{2} \mathrm{O}_{3}$ inclusion in the proper range and to control the content of $\mathrm{S}$ in liquid steel to avoid or reduce the negative effects of $\mathrm{CaS}$-bearing inclusions.

\section{CONCLUSIONS}

Thermodynamics for the formation mechanism of CaS-bearing inclusions indicates that the refining temperature is very important to the precipitation of two types of CaS. The lower the temperature, the easier it is to precipitate $\mathrm{CaS}$. One practical precipitation-area diagram of oxide-sulfide duplex inclusion was established under the condition of fixing $\mathrm{S}$ content. To explain the formation mechanism of oxide-sulfide duplex inclusion, an unreacted core model of evolution of the $\mathrm{CaO}-\mathrm{Al}_{2} \mathrm{O}_{3}$ system into the $\mathrm{CaO}-\mathrm{Al}_{2} \mathrm{O}_{3}-\mathrm{CaS}$ system was established. A mass fraction of $\mathrm{CaS}$ that was precipitated in Reaction [4] in a generated $\mathrm{CaO}-\mathrm{Al}_{2} \mathrm{O}_{3}$ $\mathrm{CaS}$ inclusion can be calculated and predicted based on the precipitation-area diagram and the model.

The observation results for the deformation of six kinds of CaS-bearing inclusions during the rolling process indicate that oxide-sulfide duplex inclusion contains less $\mathrm{CaS}$ and does not prevent the plastic deformation of whole inclusion. But when CaS in the oxide-sulfide duplex inclusion layer accounts for more, it will make the melting point of the layer rise and prevent the plastic yielding of whole inclusion. The deformations of low-modified calcium aluminates wrapped by pure $\mathrm{CaS}$ have different degrees of harm. For some time, pure $\mathrm{CaS}$ has some protective and cushioning effect on calcium aluminates, keeping it intact and preventing it from stabbing the steel body. The plastic deformation region of oxide-sulfide duplex inclusion is preliminary confirmed. It is important to modify $\mathrm{Al}_{2} \mathrm{O}_{3}$ inclusion to the proper degree and to decrease the $\mathrm{S}$ content in liquid steel to avoid or reduce the negative effects of CaS-bearing inclusions.

\section{ACKNOWLEDGMENT}

The authors acknowledge National Natural Science Foundation of China (No. 51434004, U1435205) for the financial support.

\section{OPEN ACCESS}

This article is distributed under the terms of the Creative Commons Attribution 4.0 International License (http://creativecommons.org/licenses/by/4.0/), which permits unrestricted use, distribution, and reproduction in any medium, provided you give appropriate credit to the original author(s) and the source, provide a link to the Creative Commons license, and indicate if changes were made.

\section{REFERENCES}

1. M.K. Sardar, S. Mukhopadhyay, U.K. Bandopadhyay, and S.K. Dhua: Steel Res. Int., 2007, vol. 78, pp. 136-40.

2. G. Ye, P. Jonsson, and T. Lund: ISIJ Int., 1996, vol. 36 (Supplement), pp. S105-08.

3. L. Holappa, M. Hämäläinen, M. Liukkonen, and M. Lind: Ironmak. Steelmak., 2003, vol. 30, pp. 111-15.

4. S.K. Choudhary and A. Ghosh: ISIJ Int., 2008, vol. 48, pp. 1552-59.

5. Jing. Guo, Shusen. Cheng, and Zijian. Cheng: Steel Res. Int., 2013, vol. 84 , pp. $545-53$.

6. G.K. Sigworth and J.F. Elliott: Met. Sci., 1974, vol. 8, pp. 298-310.

7. O. Kubaschewski, C.B. Alcock, and P.J. Spenscer: Materials Chemistry, 6th ed., Pergamon Press, Oxford, 1993, p. 169.

8. H. Suito and R. Inoue: ISIJ Int., 1996, vol. 36, pp. 528-36.

9. D.L. Sponseller and R.A. Flixm: Trans. Metall. Soc. AIME., 1964, vol. 230 , pp. $876-80$.

10. G.G. Mikhailov and A.G. Tyurin: lzv. Akad. Nauk SSSR Met., 1984, vol. 4, pp. 10-15.

11. R. Inoue and H. Suito: Steel Res. Int., 1994, vol. 65, pp. 403-09.

12. S.W. Cho and H. Suito: Steel Res. Int., 1994, vol. 34, pp. 265-69.

13. L.K. Liang, M.C. Che, and Y. Huai: Metallurgical Thermodynamics and Kinetics, Northeast Technology University Press, Shenyang, 1989.

14. B. Korousic: Steel Res. Int., 1991, vol. 62, pp. 285-89.

15. T. Fujisawa, C. Yamauchiand, and H. Sakao: Iron and Steel Cong., 6th Int. vol. 1, p. 201, ISIJ, Tokyo, 1990.

16. X.H. Huang: Iron and Steel Metallurgy Principle, 3rd ed., Metallurgical Industry Press, Beijing, 2012, p. 436.

17. T. Kimura and H. Suito: Metall. Mater. Trans. B, 1994, vol. 25B, pp. 33-42.

18. C.E. Cicutti, J. Madias, and J.C. Gonzalez: Ironmak. Steelmak., 1997 , vol. 24 , pp. $155-59$. 